\title{
The Analysis of Good Corporate Governance, Corporate Social Responsibility and, Firm Size Toward Firm Value
}

\section{Volta Diyanto*, Riska Natariasari}

Faculty of Economics and Bussines, Universitas Riau, Indonesia

*vdiyanto@gmail.com

\begin{tabular}{|c|c|}
\hline Article Info & Abstract \\
\hline Received : $2019-05-28$ & \multirow{4}{*}{$\begin{array}{l}\text { This research aims to analyze the effect of good corporate } \\
\text { governance, corporate social responsibility, and the firm size } \\
\text { towards the firm value. The population was banking firms listed in } \\
\text { Indonesia Stock Exchange period 2015-2018. Samples used were } \\
28 \text { firms. The analysis method used multiple linear regression. } \\
\text { The research results show that managerial ownership does not } \\
\text { have effect towards the firm value. Institutional ownership and } \\
\text { firm size have positive effect towards the firm value. Corporate } \\
\text { social responsibility has negative effect towards the company } \\
\text { value. }\end{array}$} \\
\hline : 2019-07-15 & \\
\hline Published : 2019-07-28 & \\
\hline $\begin{array}{l}\text { Key words: managerial } \\
\text { ownership, institutional } \\
\text { ownership, corporate social } \\
\text { responsibility, firm size, firm } \\
\text { value }\end{array}$ & \\
\hline
\end{tabular}

\section{Introduction}

The banking development in Indonesia shows the dynamics in economics. According Constitution of the Republic of Indonesia No.10 of 1998, November 10, 1998 bank is a business entity that its activities collect funding from the public in the form of demand deposits, savings, and distribute fund to the public by loans to improve commonwealth. Some banking cases that occurred in Indonesia such as Century Bank's case in 2008. The crisis of Century Bank was caused by bank internal problems, namely the fraud by the bank's management to customers. This case impacts to losing customers and investors' trustworthy to the bank and other banks that less the value of banking companies. The enhancement of banking companies value enhancement is needed. The company value is one of company objectives, beside achieving maximum benefit and prosperity of the owner of the company or stockholders (Savitri, 2016).

\section{The Basis of Theory and Hypotheses}

\section{The value of company}

The value of company is the market value or price that applies to the company's common stock (Brigham, 1996). It is very important because the high value of the company impact to the high prosperity of stockholders. Tobins $q$ is an indicator to measure company performance, especially about company value, which shows management performance in managing company activities. The Tobin's $Q$ ratio calculated using this following formula:

Where:

$$
\mathbf{Q}=\frac{E M V+D}{E B V+D}
$$

$\mathrm{Q}=$ company value,

EMV = Equity Market Value, obtained from the closing price of the closing price at the end of the year with stock number at the end of the year,

$\mathrm{EBV}=$ Book value from equity (Equity Book value), which is obtained from the difference in total company assets with total liabilities,

$\mathrm{D}=$ Book value of total debt. 


\section{Managerial ownership}

Jensen \& Meckling (1976) state that managerial ownership is one of the corporate governance mechanisms that can be a device in controlling agency problems. Managerial ownership can be calculated as follows:

\section{Institutional Ownership}

$$
\mathrm{KM}=\frac{\text { The total sctock of management }}{\text { The total stock of corporate }}
$$

Institutional ownership is the number of stock owned by the institution of the total amount of stock capital of managed company (Boediono, 2005). Institutional ownership has a very important role in minimizing agency conflicts that occur between managers and stockholders. Jensen \& Meckling (1976) Institutional Ownership can be calculated as follows:

$$
\text { KInst }=\frac{\text { The total sctock of institution }}{\text { The total stock of corporate }}
$$

\section{Corporate Social Responsibility}

According to Lang and Lundholm (1993), corporate characteristics can explain the wide variety of voluntary disclosures in annual reports, company characteristics are predictors of quality from disclosure. The total of CSR disclosure in the bank's annual financial statements stated in the Corporate Social Responsibility Index (CSRi) done by observing whether there is an item of information specified in annual report, if it is not in the annual report then its score 0 , and otherwise, if it is in the annual report then its score 1. The broad index of CSR disclosure (CSRi) in the company is formulated as following:

$$
\operatorname{CSRDIj}=\frac{\sum X i j}{N j}
$$

Information:

CSRDIj = Corporate Social Responsibility Disclosure index Company j,

$\mathrm{Xij} \quad=$ Number of items disclosed by company $\mathrm{j}$,

$\mathrm{Nj} \quad=$ Number of CSR disclosure items (74)

\section{Company Scale}

According to Sulistyanto (2008) the company scale is measured by the total assets of company. The company scale in this study reflects the size of companies that appear in the total assets value of company. Larger scale company has a tendency for more investors to pay attention to the company. The scale of the company is formulated as following (Waryanto, 2010):

\section{SIZE $=$ Ln (total assets)}

\section{Hypothesis}

The formulation of the hypothesis in this study are:

$\mathrm{H}_{1}$ : Managerial ownership has an effect on company value,

$\mathrm{H}_{2}$ : Institutional ownership affects the value of the company,

$\mathrm{H}_{3}$ : Corporate Social Responsibility influences the value of the company,

$\mathrm{H}_{4}$ : The scale of the company influences the value of the company. 


\section{Research Method}

\section{Population and Sample}

The population of this study are banking companies listed on the Indonesia Stock Exchange in 2015-2018. The sample of this study was 28 companies. The technique of collecting data used the documentation study method and literature study. The method of analysis used multiple linear regression.

\section{Research Results and Discussion}

The descriptive statistics provide a general description of the sample of research object. The data explanation through descriptive statistics is expected to give first view about research issues. The descriptive statistics from banking companies sample listed on the IDX in 2015 -201 8 can be presented as this following table:

Table 1. Descriptive Statistics Test Results (N=140)

\begin{tabular}{lcccc}
\hline & Minimum & Maximum & Mean & Std. Deviation \\
\hline Managerial Ownership & 0.000 & 0.282 & 0.006 & 0.0381 \\
Institutional Ownership & 11.470 & 100.000 & 60.330 & 24.883 \\
CSR & 0.105 & 0.881 & 0.553 & 0.192 \\
Firm Size & 8.085 & 24.982 & 15.359 & 4.814 \\
NP & 0.558 & 1.479 & 1.089 & 0.134
\end{tabular}

Valid N (listwise)

Source: Results of SPSS 2019

Based on Table 1, it can be seen that the managerial performance variable has a 0.000 as the lowest value and 0.282 as the highest value and also 0.006 as average value, the Devia standards is 0.038 . Institutional performance has maximum value 100,000 and the lowest value is 11.470 , the average value is 60.330 and the standard deviation is 24,883 . CSR has the lowest value 0.105 , the highest value is 0.881 and has an average value of 0.553 and standar deviation is 0.192 . The company scale has maximum value 24.982 and lowest is 8.085 , the average value is 15.359 , and standard deviation is 4,814 . The lowest value of company is 0.558 and the highest value is 1.479 , with an average is 1.089 with a standard deviation is 0.134 . 
The Analysis of Good Corporate Governance, Corporate Social Responsibility and, Firm Size Toward Firm Value

Table 2. Doubled Linear Regression

\begin{tabular}{lccccc}
\hline \multirow{2}{*}{ Model } & \multicolumn{7}{c}{ Coefficients $^{\mathbf{a}}$} \\
\cline { 2 - 4 } & Unstandardized Coefficients & $\begin{array}{c}\text { Standardized } \\
\text { Coefficients }\end{array}$ & t & Sig. \\
\cline { 2 - 4 } (Constant) & 0.993 & 0.048 & & & \\
KM & -0.304 & 0.244 & -0.086 & -1.246 & 0.215 \\
KI & 0.001 & 0.000 & 0.260 & 3.503 & 0.001 \\
CSR & -0.204 & 0.050 & -0.292 & -4.071 & 0.000 \\
UP & 0.008 & 0.002 & 0.292 & 3.984 & 0.000 \\
\hline
\end{tabular}

a. Dependent Variable: Firm Value

Source: Data Processed SPSS 2019

The effect of managerial ownership on company value. It is not true that managerial performance has a significant influence of company value. The low managerial ownership can not reduce agency conflicts so that the company's objective in achieving high company values is not achieved. The effect of institutional ownership of company values. It is true that the institutional performance has a significant effect on company value. The stronger level of control by the stockholders / investors, it will reduce the agency cost and the value of the company will be improve. The effect of Corporate Social Responsibility on Corporate Values. It is true that CSR has a significant influence on the value of the Company. Companies which have CSR bring a positive image in the community and businesses that have an influence in rising the company value. The effect of company scale in company value. It is true that the scale of the company has a significant influence in the value of the company. Maximizing company scale will makes easier for investors to get information about the company condition which can be seen from the company value (Savitri, 2018).

\section{Conclusion and Suggestion}

\section{Conclusion}

Based on the analysis result and discussion above, thus it can be concluded that managerial ownership does not have effect towards the firm value. Institutional ownership, the firm size, and Corporate Social Responsibility has effect towards the company value.

\section{Suggestion}

In the measurement to count index of corporate governance on public firms in Indonesia, it is suggested to use index published by Indonesian Institute of Corporate Governance (IICG) which is Corporate Governance Perception Index (CGPI) published in mass media every year.

\section{References}

Boediono., \& Gideon. S.B. (2005). Profit Quality: The Study on The Effect of Corporate Mechanism and The Impact of Profit Management by Using Path 101 Analysis. Accounting National Symposium 8 Solo on 15-16 of September 2005.

Brigham, E. F., Gapenski., \& Louis C. (1996). Intermediate finance managemen, fifth Edition. Harbor Drive.

Brigham,F., \& J. Houston. (2001). Financial Management. Eighth Edition. Jakarta: Erlangga 
Ghozali, I., \& A. Chariri. (2007). Accounting Theory. Board of Publisher Diponegoro University: Semarang.

Ghozali, I., \& Yusfaningrum, K. (2005). The Analysis on The Effect of Budget Participation Towards Managerial Performance Through Budget Purpose Commitment and Job Relevant Information (JRI) as Intervening Variable (The Research on Manufacture Companies in Indonesia), Accounting National Sympositum VIII, Solo.

Ghozali, I. (2005). Multivariate Analysis Application with SPSS Program. Diponegoro University. Semarang.

Ghozali, I. (2011). Multivariate Analysis Application with SPSS Program. Fourth Edition. Semarang: Publisher Diponegoro University.

Hackston, D., \& Markus J. M. (1996). Some Determinants of Social and Environmental Disclosure in New Zealand Companies. Accounting, Auditing and Accountability Journal. 9(1), 77-108.

Ghozali, I. (2011). Multivariate Analysis Application with IBM SPSS 19 Program. The Board of Publisher: Diponegoro University, Semarang.

Jensen, M. C., \& W. H. Meckling. (1976). Theory of the Firm: Managerial Behavior, Agency Costs, and Ownership Structure. Journal of Financial Economics, 3(4), 305-360.

Lang, M., \& R. Lundholm. (1993). Cross sectional determinants of analysist rating of corporate disclosure. Journal of Accounting Research. 31(2), 246-271.

Riduwan, E. A. K. (2012). How to use and comprehend Path Analysis. Bandung: Alfabeta.

Savitri, E. (2016). Corporate Governance Mechanism and The Moderating Effect of Independency on The Integrity of Financial Reporting. Investment Management and Financial Innovations. 13(4), 68-74.

Savitri, E. (2018). Relationship Between Family Ownership, Agency Costs Towards Financial Performance and Business Strategy as Mediation. Business: Theory and Practice. 19, 49-58.

Sulistyanto, S. (2008). Profit Management: Theory and Empirical Model. PT.Gramedia Widiasarana Indonesia: Jakarta.

The Law No. 10 in 1998 About Banking.

Wahyudi, U., \& H. P. Prasetyaning. (2005). The Implication of Ownership Structure Towards Firm Values: With Financial Decision as Intervening Variable. Accounting National Symposium IX. Padang 23-26 of August.

Website : www.idx.co.id 